\title{
Base of the Skull
}

National Cancer Institute

\section{Source}

National Cancer Institute. Base of the Skull. NCI Thesaurus. Code C12493.

The portion of the skull that forms the floor on which the brain lies. The internal surface of the cranial base has three large depressions that lie on different levels known as the anterior, middle, and posterior cranial fossae. 